\title{
Examination of Wonder Film in the Context of Social Stigma and Internal Stigma Towards Individual Differences
}

\section{Research Article}

\section{Nalan ALTAY', Melda Meliha ERBAS²}

${ }^{1}$ Manisa Celal Bayar University, Faculty of Education, Department of Social Studies, Manisa, Turkey, ORCID: 0000-0003-0807-7494

${ }_{2}^{2}$ Manisa Celal Bayar University, Faculty of Education, Department of Counseling and Guidance, Manisa, Turkey, ORCID: 0000-0001-8640-5356

To cite this article: Altay, N., \& Erbas, M. M. (2021). Examination of wonder film in the connection of social stigma and internal stigma towards individual differences, International Online Journal of Educational Sciences, 13(2), 362-389.

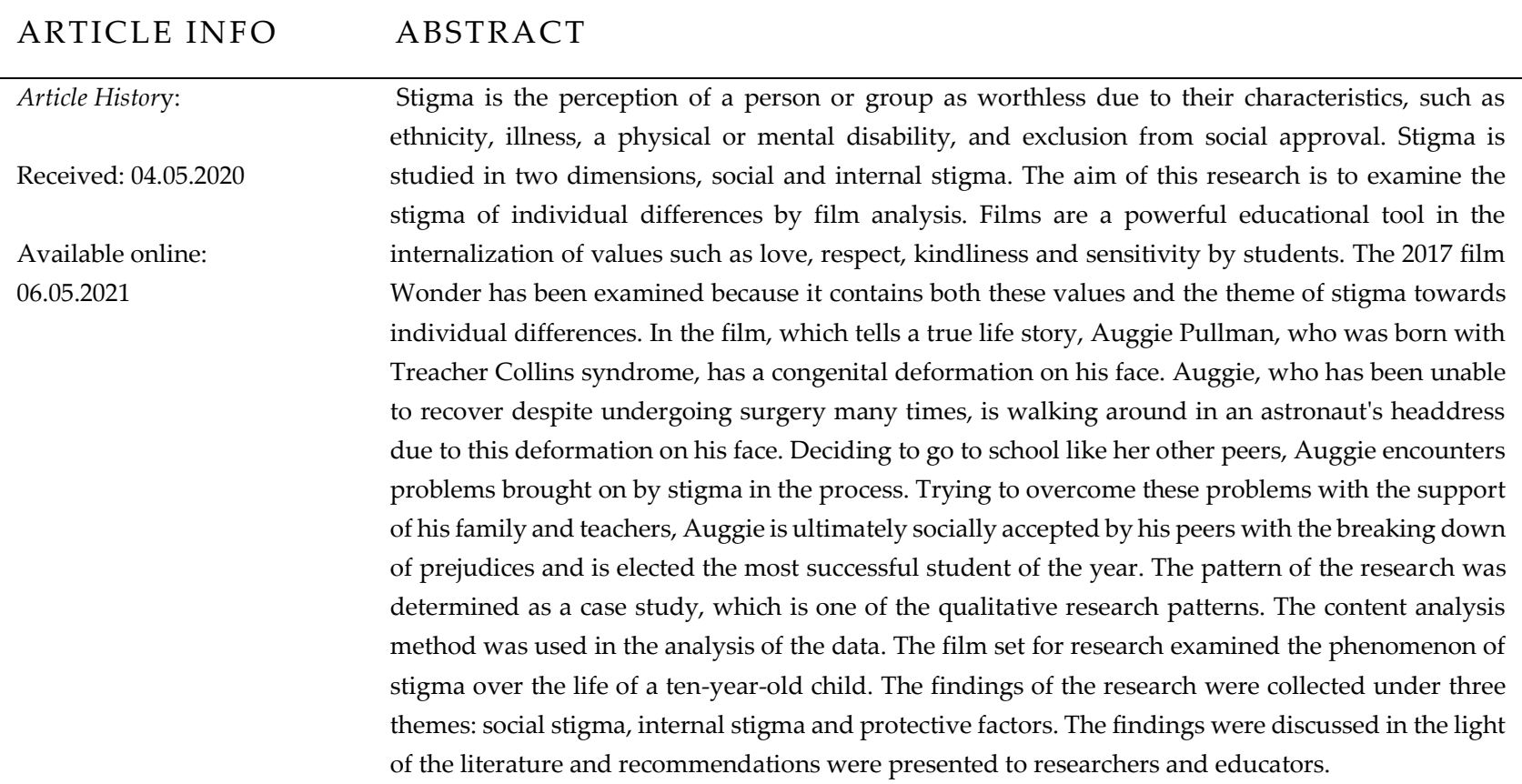

Keywords:

Individual differences, social stigma, internal stigma, film analysis 


\section{Introduction}

Stigma is the perception of a person or group as worthless due to their characteristics such as ethnicity, illness, sexual orientation, physical or mental incompetence, and exclusion from social approval (Page, 2015). A person can be stigmatized because of many characteristics. These stigmas can be caused by innate characteristics of a person, as well as by variables such as socioeconomic status, physiological or psychological health problems (Johnson, Richeson \& Finkel, 2011; Yang et al., 2007; Link \& Phelon, 2001; Fiske, 1998). Stigmatization is studied in two dimensions, social and internal stamping. Through social stigma, it is emphasized that the person or group being stigmatized is different, and negative characteristics can be attributed to the people being stigmatized because of this difference. As a result of social stigma, the stigmatized individual may be subjected to discrimination by losing status in society, and their value may decrease in society. Because stigma involves others ' negative perceptions of the individual, the pattern arises as a result of judgments, discrimination, and labeling (Corrigan, Larson, \& Rüsch, 2009; Link \& Phelon, 2001). Stigmatizers exhibit negative emotional reactions and behaviors that are compatible with their stereotypes (Corrigan et al., 2009). When a person or society encounters a situation or person that scares or bothers them, they often tend to exclude and alienate them from themselves. Discrimination is a condition that involves the processes of not wanting intimacy with the stigmatized individual, restricting, inhibiting and excluding the individual from society. A person who qualifies as different from others in society can be discriminated against in many areas of life (Taşkın, 2007).

One of the underlying causes of stigma is labeling. Labeling has negative and destructive consequences for individuals, such as intense feelings of shame and impaired spiritual balance (Cunningham, Sobell, \& Chow, 1993). One possible consequence of labeling is exclusion in social settings. Social exclusion is defined as a lack of acceptance by society, a break in social bonds between the individual and society (De Haan, 2000). The negative attitudes and experience of social exclusion faced by the individual can cause serious mental distress. Individuals exposed to social exclusion often experience emotional and psychological difficulties (Timurturkan et al., 2019). Labeling can sometimes increase and turn into bullying. Bullying, defined as behavior intended to intentionally hurt and offend a person, is quite common among children(Griffin \& Gross, 2004). Children who are bullied are generally physically weaker, self-confident, sensitive, anxious, unhappy and shy (Marano, 1995). It is also noted that children who are victims of bullying have a lower level of peer acceptance. On the other hand, it is emphasized that most children with special needs are bullied in educational settings (Buchanan \& Winzer, 2001). As can be seen, stigma can cause a person to face many negatives in social settings. But no matter how stigma arises, individual coping or avoidance reactions can stop or increase these reactions (Link et al., 2004).

Another dimension of stigma is internal stigma. Internal stigma is the fact that a person internalizes the stereotypical judgments that others create towards him and, as a result, moves away from society due to feelings such as worthlessness, shame that he feels (Corrigan, 1998). According to Taşkın (2007), internal stigma can sometimes also occur independently of social stigma. That is, although the individual does not experience stigma or discrimination, he or she can self-stigmatize because of the individual differences he or she has. Individuals who are potentially likely to be stigmatized, assume that they will become worthless because of stereotyping and may be discriminated against in society. For this reason, they are able to adopt coping strategies such as self-concealment and social introversion in society (Link, 1987). Awareness of stigma by the stigmatized can lead to a shift away from society. Because the idea that the individual is different, a sense of shame and a negative self-perception can be seen (Camp, Finlay, \& Lyons, 2002). Self-perception is a judgment that shows one's self-assessment of one's self. Confirming the self-concept that a person creates as a result of self-assessment is expressed by positive self-perception. Comparisons that individuals make about themselves and others when interacting with others are defined as social comparison. It has been suggested 
that all views of the individual regarding himself and others are formed by these comparisons (Abrams \& Hogg, 1988). Self-perception plays a key role in the individual's perception of stigma. Negative self-perception leads to a greater sense of stigma, while stigma can also have a negative impact on an individual's selfperception (Verhaeghe, Bracke, \& Bruynooghe, 2008; Werner, Aviv, \& Barak, 2007). According to the sociocognitive model of Corrigan and Watson (2002), these individuals create a negative image of themselves and develop a biased and discriminatory perception of themselves with this image. This perception also leads to internal stigma (Kaplan, Vogel, Gentile, \& Wade, 2011; Vogel, Shechtman, \& Wade, 2010). Due to internal stigma in individuals, conditions such as low self-efficacy perception and decreased quality of life can often be observed (Larson \& Corrigan, 2010; Marcussen, Ritter \& Munetz, 2010; Vauth et al., 2007; Vogel, Wade, Wester, Larson, \& Hackler, 2007; Corrigan, Watson, Byrne, \& Davis, 2005; Camp, Finlay, \& Lyons, 2002).

Social support and social acceptance for stigma and discrimination have been found to have a positive empowering effect (Goldberg \& Smith, 2011; Hancock \& Oulton, 2003). At a time when bullying and violence are increasing, internalizing values such as love, respect, benevolence and sensitivity of individuals is very important both for increasing social acceptance and for educating psychologically healthy individuals. Films are a powerful educational tool in the internalization of these values by students. In addition to their visual and auditory aspects, their films are high in catchiness, as they also have color and movement characteristics. Because of these characteristics, they provide opportunities for the formation of desired behavioral changes that increase motivation by addressing different sensory organs of students. In other words, they can help students develop different perspectives and develop creative thinking skills by focusing on problems. For this reason, films can be used as an effective tool in the educational environment (Tofur, 2018; Yurdigül, 2014). On the other hand, it is considered important to watch these and similar films and discuss them in educational settings in order for teachers and candidate teachers to recognize their own attitudes about individual differences, develop different perspectives, understand how to approach them as an educator when they encounter similar situations in real life by empathizing with the stigmatized individual. Considering that films are fictional imitations of real life, it can be said that students, teacher candidates and educators can gain life experiences through films. On the other hand, at all levels of education, including teacher candidate training processes, scientific studies on the use of films in education are considered necessary in order to increase the use of films as educational material. It is also believed that the study will contribute to the field in terms of providing ideas for films on education and other research that can be done on the use of film in educational processes. In this context, the 2017 film Wonder was considered worthy of study in terms of its inclusion of social stigma and internal stigma themes for the individual differences that constitute the subject of the study, as well as the values that are intended to be acquired by students in educational settings. This film covers fundamental issues such as social exclusion, discrimination, bullying, stereotyping, bias, and labeling that can be caused by stigma.

The aim of this research is to examine the stigma of individual differences by film analysis. The aim of this film, which contains the themes of stigma in individual differences and describes the experiences of the individual in the process of stigma, is to use it in educational processes so that teachers, teacher candidates and students question their own attitudes and develop awareness. Another goal of the research is to provide researchers with a new perspective to spread the use of film in educational processes.

\section{Method}

In this chapter, there are model of the study, data collection tools, story of the movie, research steps and explanations on validity and reliability. 


\section{Model of Study}

Design of the study was determined as case study, one of qualitative research designs. The case study is an empirical type of research that examines a current (up-to-date) fact together with its context in real life in detail and holistically, and it is used frequently in the field of educational sciences (Merriam, 2018). Context analysis was used to analyze data. The context analysis presents forth existence, meanings and relationships of certain words and concepts which take a place within a text; analyzes them; and therefore, makes inference of message, given by the text. This method is a method that is used not only over texts but also in a pretty wide area such as visual elements, television programs, theater performances and newspaper articles etc. (Büyüköztürk, Çakmak, Akgün, Karadeniz, \& Demirel, 2014).

\section{Data Collection Tools}

Movies, a tool of communication, are also reflection of real life (Altan, 2016). Another function of movies is that they can refer to individual's problems by providing with opportunity to look one's problems from outside, and that they can develop alternative approaches in solving these problems by making sense of these problems; and in this sense, they can help the individual in solving various individual problems (Doruk \& Fişıloğlu, 2007).

In this study, the movie titled "Wonder" was determined as analysis unit. The reason for this movie to be opted for is because it is thought that this movie represents properly stigmatization fact of individual differences which is the research subject.

\section{Story of the Movie}

In the movie, based on a real life story, a section from difficulties which August Pullman experienced, who was born with Treacher Collins syndrome, is treated. August Pullman (as Auggie in the movie) is ten years old and graduated to 5th grade in the school. He lives with his mother, father and Via, his elder sister. What makes him different from other children is that there is inborn deformity on his head and face due to Treacher Collins syndrome. Inspite of tens of surgical operations he has undergone, this deformity has not recovered. That is why Auggie has never been to school; was educated by his mother; and his relationship with outside world was through an astronaut helmet. His mother wants to prove that Auggie has no difference from his peers by sending Auggie to the same school together with other children now. However, due to the difference in his appearance, Auggie has been subjected to the stigmatization by his peers in the school to which he has been; been excluded; and even has been bullied (undergone bullying). On the other hand, during this process, he compares himself with the others since he has been different from his peers; feels himself worthless; and thoughts that other children in the school do not want him among them. This situation turned his emotional world upside-down. Auggie summarized the situation at which he was with the sentence that "We are living in a weird world where the good people should go to psychologist in order to learn coping with things which the evil ones do". During the next process, Auggie gains acceptance by other students in the school with the support of his family and teachers and he receives the best student award of the year at the end of school term. In the movie, it is emphasized that no deficiencies or differencies are obstacle to us. The movie is made in USA and was released on 2017. Stephen Chbosky is director of the movie.

\section{Stages of the Study}

The study is composed of five different stages: In the first stage, literature review of stigmatization fact for individual differences was made and an institutional framework was formed. In the next stage, the movie was watched by researchers. Later on, researchers determined scenes on which codes were mentioned in the movie, which are related to social stigmatization and internal stigmatization by watching separately the movie 
several times. In the following stage, reliability of the study was presented by comparing codes which coders made. In the final stage, findings were interpreted in compliance with the literature.

\section{Validity and Reliability of the Study}

In the scientific research, "reliability" is associated with repeatability of scientific findings while "validity" is with accuracy of them (Yıldırım \& Şimşek, 2013). In qualitative researches, there are a series of strategies different from quantitative researches in order to increase reliability and validity (Başkale, 2016). The movie, which was subject of the study, was watched separately by two researchers several times. In the quantitative researches, internal validity or credibility is associated with adequacy of revealing reality outside world of research findings (Merriam, 2018). In the study, while themes and codes were being created to provide internal validity, the relevant literature was examined and conceptual framefork concerning the subject was formed. In the qualitative researches, external validity is related to whether or not the results obtained could be generalized to external events and environments. In other worlds, it is related to what degree results of the relevant study could be implemented to other situations (Merriam, 2018). The fact that plot of the movie is based on a true story is the factor strengthering external validity. In this study, triangulation technique was used to be able to provide internal validity and two reseachers made data encoding independently. Later, codes by these two researchers were examined by putting together, and those upon which there was a consensus and no consensus were determined. To determine percentage of the reliability, formula on P (Agreement Percentage) $=[\mathrm{Na}$ (Consensus) $/(\mathrm{Nd}$ (Dissensus) X 100 (Miles \& Huberman, 1994), was used and similarity rate between coders was found as $89 \%$. For Miles and Huberman (1994), consensus between coders should be at least $80 \%$ so that reliability could be provided. Based on this data, the study was accepted as reliable. In the study, the path followed, method used, and problem status, for the purpose of providing external reliability, were presented in detail. Therefore, to guide to similiar studies which would be carried out in the future was targeted.

\section{Findings}

As a consequence of qualitative data analysis, findings for stigmatization on the movie "Miracle" were subsumed under three themes to be social stigmatization, internal stigmatization and protective factors. Four codes, including social exclusion, stereotypes, bullying and labelling, emerged under the theme of social stigmatization; three codes, including self-concealment, social comparison, negative self-perception, under the theme of internal stigmatization; and two codes, including social acceptance and social support, under the theme of protective factors. On the movie, twenty-five scenes were determined concerning stigmatization to which the protagonist, ten-year-old Auggie Pullman, was exposed. Thirteen of these scenes were associated with social stigmatization while the remaining twelwe is with internal stigmatization. Besides, there are six scenes which were determined in relation to protective factors. While four of these scenes are associated with social support, two ones are with social acceptance. In the Table 1, knowledge on what hour, minute and second of the movie of scenes for social and internal stigmatization took place at were given.

Table 1. Time schedule for social stigmatization, internal stigmatization and protective factors which were mentioned on the movie

\begin{tabular}{lll}
\hline Theme & Code & Time \\
\hline & Social Exclusion & $00: 14: 31$ \\
& & $01: 09: 01$ \\
\cline { 2 - 3 } Social Stigmatization & Stereotypes & $00: 08: 02$ \\
& & $00: 45: 28$ \\
\cline { 2 - 3 } & Bullying & $00: 15: 22$ \\
& & $00: 19: 39$
\end{tabular}




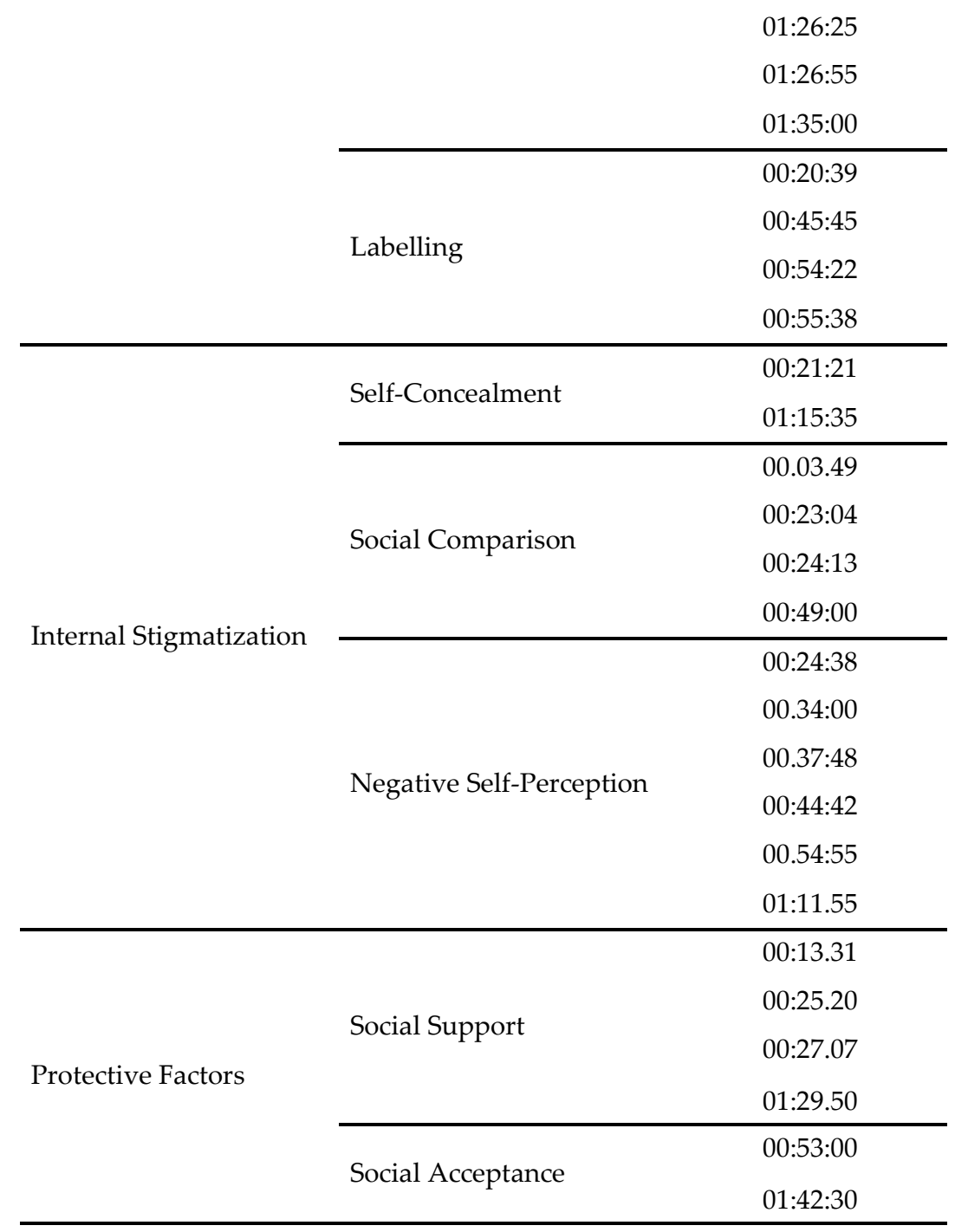

\section{Social Stigmatization}

Four codes, including social exclusion, stereotypes, bullying and labelling, take a place under the theme of social stigmatization.

\section{Social exclusion}

Scene 1: Everyone looks at Auggie while he is entering through schoolyard at the minute 14:31.00 of the movie. Auggie walks through schoolyard to the classroom in a head bent way.

Scene 2: Teacher gives project paper to the classroom at the minute 01:09:01 of the movie and wants everyone to be partner with one's deskmate. But, two desk mates, who are sitting at back desk, do not want Jack Will, who is sitting by Auggie, to study together Auggie and they say teacher that they want Jack Will to join with them into group work, too. The fact that his other peers stay away from Auggie due to his (physical) appearance is seen as an example to social exclusion.

\section{Stereotypes}

Scene 3: (Before school opens, Auggie and his family come to the school within the scope of orientation process. School management calls also three students to the school and wants them to introduce the school to Auggie and to help him during orientation process. Those children show Auggie around the school at the minute 00:08.02 of the movie, and one of the children passes in front of Auggie while entering into science lab and says "Science course is a quite difficult one, and for this reason, you probably would not come here". 
Scene 4: (All students wore costume on that day due to Halloween. Also Auggie goes to school with his costume; he is very happy, because he has mask on his face and nobody recognizes him.) Three students talk about him at the classroom door at the minute 00:45:28 of the movie. While one of children says "I would wander always with hood if i looked like him", the other says "I would kill myself if I looked like him. Auggie moves away from there unhappily. One each example of stereotypes which other children have towards Auggie is seen on these two scenes.

\section{Bullying}

Scene 5: Entered into the classroom for the first time, Auggie pulls out/grabs a chair upon that the teacher, who is present at that time in the classroom, says "please, everyone, find a place for oneself" at the minute 00:15:22 of the movie. But, one student, who is sitting at the back side, says "it is mine" by putting the chair. Auggie finds another chair for himself and sits on it.

Scene 6: Children eat in the canteen at the minute 00:19:39 of the movie. Auggie chews his meal in a different way from the others at another table due to deformity in his mouth. His classmates, who are at other table, stare at him. One of his classmates, coming near to him, says "May I sit down here?" and that classmate moves away from there by saying "You are eating just as Monster Saylak".

Scene 7: Auggie sits at his desk in the classroom at the minute 01:26:25 of the movie. His classmate leaves a paper in front of Auggie while passing by him. When Auggie opens the paper, there is a picture and Freddy Krueger is written beside the picture on the paper.

Scene 8: Children laugh together along school corridor at the minute 01:26:55 of the movie. They move away from the locker around which they gather when they see Auggie walking toward there. Class photograph is hanged on the locker, but Auggie has been removed from that photograph.

Scene 9: Joining in school trip, Auggie walks around forest together with his friend Jack at the minute 01.35.00 of the movie. In the meantime, three children, who are elder, come to them. These three children shudder when they see Auggie. Such conservation happens among them:

- "Wow, look at that face!"

-“He is a freak."

-"I have never seen something uglier in my life before."

-"Maybe, he is an orc".

They mock with Auggie. Jack Will challanges them and a fighting comes to blows. The fact that other children gibe to Auggie and that they exclude him on each one of these scenes is a sign to peer bullying.

\section{Labelling}

Scene 10: At the minute 00.20.39 of the movie, one of Auggie's classmates says him, referring to his braid on back of his hair, "Hey, freak! Did you hear? Dart arrow-hair braid lingered in the fifteen years ago". At the minute 00.20.50, while the school is getting out, his friends say eachother "see you later". In the meantime, one of them says Auggie "See you the vomitted freak!".

Scene 11: Auggie wore ghost mask due to Halloween at the minute 00.45.45. of the movie. He is very cheerful because he does not have to drop his head and he says that to himself: Halloween is the best ever holiday for me...neither I recognize the person who is across me and nor that person recognizes me. That is very good. Particularly, due to people who escape me thinking that i have infectious.".

Scene 12: Jack Will comes to table at which Auggie sits alone by taking his meal at the minute 00.54.22 of the movie. But, Auggie does not want to talk to Jack Will whom Auggie have heard Jack Will's talks about 
Auggie. Jack Will asks Auggie "What is the problem?". Auggie says "Leave me alone!". Jack's friends at the other table call him. They say, "Come and sit with us". Such conservation happens among children at this table:

-“What happened?

-“Maybe, Jack touched Auggie, could not wash his hands and he has finally catched plague”.

Scene 13: Auggie says female student named Summer, who says that she want to become friends with him, coming to him, "you do not have to become friends with me" at the minute 00:55:38 of the movie. Summer convinces that she really wants to become friends with him. Both say that they need a good friend, and shake hands. One of female students, watching them at the other table, says "also Summer catched plague". It can be said that other children's behaviours and what they said for Auggie on each one of these scenes are one each example to labelling.

\section{Internal Stigmatization}

There are three codes, including self-concealment, social comparison and negative self-perception, under the theme of internal stigmatization.

\section{Self-Concealment}

Scene 1: Auggie came home sadly upon his classmates mocked with braid in his hair in the classroom at the minute 00:21:21 of the movie. He enters into his elder sister's room without knocking. At that point, however she says he should knock at door, he cuts his braid in his hair by scissors of which he puts out the drawer, and then he wears his astronaut helmet.

Scene 2. Auggie, and his classmate, Jack Will, play online MineCraft game at the minute 01:15:35 of the movie. Jack enviously admires towers which Auggie constructs. He says "Did you construct these, Auggie? That is incredible!" but, Auggie conceals himself wandering with an astronaut helmet within the game in the on online platform too. The fact that Auggie does not want to show his face using an astronaut helmet both in real life and in the virtual environment on these scenes is one each example to self-concealment.

\section{Social Comparison}

Scene 3: Auggie's mother and father discuss in the bedroom about whether or not Auggie could start the school, at the minute 00.03 .49 of the movie. Mother says Auggie is ready to start the school, and she could not train Auggie at home to the end of her life. But, father says this would pose various difficulties.

Mother: - His all peers is going to start middle school this year. He will not be the newest child there".

Father: says "Okay! But, he will be the only child who looks like to him there, ... This is like bringing a sheep away slaughter house. Don't you know it?"

Auggie listens these talks through slightly-opened door. He goes to his room and thinks of it this way:

-"I know that i can't be an ordinary child. Ordinary children do not scare others away from playground. Ordinary child is not stared at everywhere they go."

Scene 4: Auggie and his family have dinner with the whole family at dining table in evening of the first day of the school at the minute 00:23:04 of the minute. Auggie sit at the table with astronaut helmet because his first day at school was bad. Everyone are nervous at the dining table. His mother opens Auggie's helmet and asks him "How was your first day?". Auggie does not answer his mother and he idles around meal in his plate. Father says "We asked a question just now. How was your day?". Auggie says "Great" but Auggie is very nervous and (the fact) that his day did not go well is obvious from his all aspects. When his mother says 
“Or it was bad, don't you want to tell us?". Auggie answers "Why can't I say it was great like everyone else?" and gets up from the table.

Scene 5: Auggie and his mother talks about the first day of the scool at the minute 00:24:13 of the school. He says "They don't even talk to me. My being different is much realized" implying his friends at classroom.

Scene 6: At the minute 00:49:00 of the movie, Auggie had a bad day at the school and locked himself into his room. His elder sister enters into the room and suggests going to gather candies for Halloween. Auggie snaps at (rebuffs) her. His elder sister has now begun not to meet with her closest (best) friend and she says to Auggie "you are not the only person who has had bad days." Auggie rises his voice and asks his elder sister "Do they avoid touching you?"Well, does someone call you plague-stricken when he or she touches you accidentally?". On each one of these scenes, that Auggie compares his experiences with ordinary children and that he feels unhappy seeing him different from others can be seen as one each example to social comparison.

\section{Negative Self-Perception}

Scene 7: At the minute 00:24:38 of the movie, Auggie, whose first day at the school went bad, leaves from the dining table sadly. His mother enters after him into his room and she wants to talk to him. She sits Auggie down the bed and says Auggie to take his helmet off. Auggie cries and says "Why should I be such ugly?". His mother says he is not ugly but Auggie says: "You think so since you are my mother". His mother answers: Isn't it true of my being your mother? I think, it is true of the best. Because, I know you the best since I am your mother.

Scene 8: Everyone is in front of the blackboard to have a classroom photo taken at the minute 00.33:40 of the movie. Auggie is also there and his teacher stands back Auggie. At the moment when Photographer says "one, two, three cheese", his teacher, who is in back of Auggie, holds Auggie while going away to get out of photo frame, and his teacher mades Auggie stay at photo frame.

Scene 9: Jack Will comes to Auggie, standing alone at the canteen, at the minute 00.37:38 of the movie. Jack thanks to Auggie for helping him in the exam. In the meanwhile, Jack realizes that Auggie have not touched his meal. Auggie:

-“I don't like eating in front of other people...... chew like a pre-historic swamp tortoise while I am eating".

Scene 10: Auggie, who is going to go to school for Halloween, is very happy at the minute 00:44.42 of the movie and he goes out home in a cheer. He says "...to wear costume is incredible for me. Normally, i walk with the head bent in order not to be realized".

Scene 11: At the minute 00.54:55 of the movie, Auggie thought that Summer wanted to make friendship with him at school principal's request, by saying to Summer who come to Auggie "You don't have to do this. You don't need to be my friend. I know that you have talked to Tuesman (school principal)".

Scene 12: At the minute 01:11.55 of the movie, Via, Auggie's elder sister, has a year-end theater performance. Auggie, his elder sister and mother talk among themselves at the dining table. His mother says that his father is going to go to watch elder sister's performance and she is going to stay at home with Auggie. They say the theater play would not be suitable for Auggie and that he could get bored. His elder sister does not want that Auggie comes to theather performance. Auggie asks his elder sister "Don't you want that your cool friends see your freak brother?". On these scenes, that Auggie feels that he has to continuously walk with the head bent and that he thought others do not want to be with him, show Auggie has negative selfperception. 


\section{Protective Factors}

There are two codes, including social support and social acceptance, under the theme of Protective Factors.

\section{Social Support}

Scene 1: At the minute 00:13:31 of the movie, astronaut helmet is at his head at his first time to go to school. Via and mother say goodbye to Auggie. Father says to talk to man to man as father-son and they come toward schoolyard gate. Father says that he can not enter gate of schoolyard into and that it will not be "cool". Besides, he says "this helmet is not cool, too". Father takes off Auggie's astronaut helmet and says: "Although you know answer the question, please still raise your hand, and clean the science course out. You will feel that you are alone but you are not alone." Father supports Auggie in this talk.

Scene 2: At the minute 00:25:20 of the movie, Mother says to Auggie who had trouble in his first day at the school, showing faceprints on her face, "We all have faceprints on our faces. This shows where we are at and it is never an ugly thing." Auggie hugs his mother pleasedly. Mother's this behaviour is a sign to social support.

Scene 3: Upon (that) his friends left a note written "there is no room for freaks!" to Auggie at the minute 01.27.07 of the movie, that Auggie's teacher says "you can ask for it if you need help. You are not alone" can be showed as an example to social support.

Scene 4: Auggie's classmate, mother and school principal talk among themselves in the principal's office due to bullying behaviours by him to Auggie at the minute 01.29 .50 of the movie. Auggie's classmate got suspended for two days because of his behaviours, but his mother reacts to this. Tuesman, the school principal, says "Auggie can not change his appearance but we can change our outlook on him." Therefore, the principal both supports Auggie and he emphasizes that he expects this behaviour from other students, too.

\section{Social Acceptance}

Scene 1: At the minute 00:53:00 of the movie, Auggie's classmate says that there are four things about Auggie. "...The fourth one is the most interesting one, which I can say that I want really to be friend with Auggie since I have already known him. At first, I became friend with Auggie since my mother said me that I should behave him well. But, now I myself want to hang out together him." This situation is a sign to Auggie's gaining social acceptance by Jack, his friend.

Scene 2: The school principal is at lectern (rostrum) on year-end graduation ceremony at the minute 01.42.30 of the movie. He announces Auggie to receive award, given for model students who achieved great success. The school gives Auggie a standing ovation. This situation is a sign to social acceptance. Auggie has not got his helmet and he receives his award proudly.

\section{Discussion and Conclusion}

In this study, the phenomenon of stigma was examined through the life of a ten-year-old child with special needs, who is the protagonist of the film. It is important that the film examined in the study allows the phenomenon of stigma, which is often encountered in schools, to be examined with visual and auditory elements, that the film script is taken from a real life story, and that the film is one of the films recommended to be watched by the Ministry of Education of Turkey. In the film, the phenomenon of stigma is discussed in three themes: social stigma, internal stigma, and protective factors for stigma.

In the field, it is seen that the phenomenon of stigma is considered in two dimensions: social and internal stigma. Based on this, the phenomenon of stigma was studied in two dimensions in parallel with the field during film analysis. Under the theme of social stigma are four codes: social exclusion, stereotyping, bullying, 
and labeling. In the film, Auggie, who was homeschooled for years because of the fear that he would not be accepted due to his appearance, was subjected to discrimination and social exclusion among his peers when he started school. The stereotypes his peers had led Auggie to be labelled and even bullied. Relevant research indicates that social stigma is underpinned by factors such as labeling, discrimination and social exclusion, and that stigma can sometimes turn into bullying (Strindberg, Horton, \& Thornberg, 2020; Earnshaw et al., 2018; Thornberg, 2015). From this point of view, it is important to educate individuals to reduce the destructive actions of exclusion, judgment, labeling, discrimination or even bullying caused by stigma towards people with individual differences in all kinds of social environments, especially in educational environments.

Under the theme of internal stigma, three codes have emerged: self-concealment, social comparison, negative self-perception. In the film, elements of internal stigma are observed through Auggie walking around wearing an astronaut helmet, distancing himself from peer relationships, describing himself with labels such as 'freak, monster' that his peers say. In a study that analyzed the communication patterns used in the film Wonder, it was also noted that Auggie never considered himself like other children, and this was clearly reflected in his conversations and definitions of himself (Fikri, 2019). In literature, internal stigma is defined as the individual developing a negative image that contains prejudices by internalizing the stereotypes of others towards him and moving away from society due to feelings such as worthlessness and shame that he experiences (Corrigan \& Watson, 2002; Corrigan, 1998). From this perspective, it can be said that Auggie developed internal stigma as a result of the social stigma he was exposed to due to the individual differences he had. So he judges himself in the most severe way, even if others judge him or not. Based on this, it can be argued that internal stigma can be as damaging as social stigma, and in order to avoid internal stigma, it is important to provide the necessary social support to individuals who develop internal stigma after first implementing strategies to reduce social stigma.

Under the theme of protective factors, two codes emerged: social acceptance and social support. Looking at the field summer, there are several studies highlighting the positive impact of social support in reducing stigma and discrimination (Goldberg \& Smith, 2011; Hancock \& Oulton, 2003). Indeed, in Ningtyas' (2019) similar study about the Wonder, it was determined that the competent parenting style that his mother had and the intimate communication with his son were an important support factor for Auggie's academic success, life abilities and self-esteem development. From this point of view, it can be said that all kinds of social support, especially family support, have an important place for individuals experiencing stigma to cope with this situation. In order for social support to emerge, priority social acceptance and empathy must be formed. Films are also seen as an effective educational tool in internalizing such values, especially in educational settings (Yurdigül, 2014). In her research, Ervina (2020) stated that Wonder contains many values such as honesty, love and compassion, joy, good heart, kindness, love of life, knowledge, sincerity and self-belief and is an inspiration for teachers. Based on this, it can be argued that the use of film in educational settings is an effective direction for viewers to gain values such as tolerance and respect for individual differences through empathy with the characters of the film.

In light of the findings from the study, some recommendations were presented to educators and researchers. It is believed that the use of films in educational processes will help students better perceive, internalize events and situations, empathizing with characters, and develop critical thinking skills. Based on this, research that improves teachers ' awareness of the benefits of using films in education can be replicated. In educational faculties, teacher candidates can be given courses on the use of film in education. Educational films can be used in order to improve the professional skills and attitudes of teacher candidates within the scope of courses in educational faculties. The use of films can be disseminated at all levels of education to increase students ' awareness of issues such as stigma towards individual differences. The use of films can be increased at all levels of education to increase students ' awareness of issues such as stigma towards individual 
differences. Films can be used in parental training for students ' families. Researchers can conduct more extensive research on the use and effectiveness of films in educational settings for students of different age groups. 


\section{REFERENCES}

Abrams, D., \& Hogg, M. A. (1988). Comments on the motivational status of self-esteem in social identity and intergroup discrimination. European Journal of Social Psychology, 18(4), 317-334.

Buchanan, P., \& Winzer, M. (2001). Bullying in schools: Children's voices. International Journal of Special Education, 16(1), 67-79.

Camp, D.L., Finlay, W.M.L, \& Lyons, E. (2002). Is low self-esteem an inevitable consequence of stigma? An example from women with chronic mental health problems. Social Sci Med, 55, 823-34.

Corrigan, P.W. (1998). The impact of stigma on severe mental illness. Cog Behav Prac, 5, 201-222.

Corrigan P.W., Kerr, E. \& Knudsen, L. (2005). The stigma of mental illness: Explanatory models and methods for change. Applied and Preventive Psychology, 11, 179-190.

Cunningham, J. A., Sobell, L. C., \& Chow, V. M. (1993). What's in a label? The effects of substance types and labels on treatment considerations and stigma. Journal of Studies on Alcohol, 54(6), 693-699.

De Haan, A. (2000). Social exclusion: Enriching the understanding of deprivation. Studies in Social and Political Thought, 2(2), 22-40.

Earnshaw, V. A., Reisner, S. L., Menino, D. D., Poteat, V. P., Bogart, L. M., Barnes, T. N., \& Schuster, M. A. (2018). Stigma-based bullying interventions: A systematic review. Developmental Review, 48, 178-200.

Ervina, U. (2020). An analysıs of moral value in wonder movie (Doctoral dissertation, Universitas Stikubank).

Griffin, R.S. \& Gross, A.M. (2004). Childhood bullying: Current findings and future directions for research. Aggression and Violent Behavior, 9, 379-400.

Fikri, K. (2019). The analysis of language functions used by the main character of Wonder movie (2017) (Doctoral dissertation, Universitas Islam Negeri Maulana Malik Ibrahim).

Fiske, S. T. (1998). Stereotyping, prejudice, and discrimination. In, D.T. Gilbert \& S.T. Fiske (Eds) The handbook of social psychology (pp: 357-411). Boston, MA: McGraw Hill

Hancock, C., \& Oulton J.A. (2003). Nurses: Fighting AIDS stigma caring for all. International Council of Nurses, Geneva, Switzerland.

Johnson, S. E., Richeson, A. J., \& Finkel, E. J. (2011). Middle class and marginal? Socioeconomic status, stigma, and self-regulation at an elite university. Journal of Personality and Social Psychology, 100(5), 838-852.

Larson, J. E., \& Corrigan, P. W. (2010). Psychotherapy for self-stigma among rural clients. Journal of Clinical Psychology: In Session. 66(5), 524-536.

Link, B. G. (1987). Understanding labelling effects in the area of mental disorders: an assessment of the effects of expectations of rejection. AM Sociol Rev, 52, 96-112

Link B. G., Yang, L. H., Phelan, J. C., \& Collins, P.Y. (2004). Measuring mental illness stigma. Schizophrenia Bulletin, 30(3), 511-541.

Link, B. G., \& Phelan, J. C. (2001). Conceptualizing stigma. Annual Review of Sociology, 27, 363-385.

Marano, H.E. (1995). Big bad bully. Psychology Today, 28(5), 50-68.

Marcussen, K., Ritter, C., \& Munetz, R. M. (2010). The effect of services and stigma on quality of life for persons with serious mental illness. Psychiatry Serv, 61, 489-94. 
Merriam, S. B., (2018). Qualitative research, A guide to design and implementation. Turan, S. (Çev.Ed.). Ankara: Nobel Akademi.

Miles, M., \& Huberman, A. (1994). Qualitative data analysis: An expanded Sourcebook. (2nd ed). Thousand Oaks, CA: Sage.

Ningtyas, A. N. (2019). An analysis on isabel pullman's parenting style towards August Pullman in "Wonder" movie (Doctoral dissertation, University of Muhammadiyah Malang).

Page, R. M. (2015). Stigma. Psychology Press.

Strindberg, J., Horton, P., \& Thornberg, R. (2020). The fear of being singled out: pupils' perspectives on victimisation and bystanding in bullying situations. British Journal of Sociology of Education, 41(7), 942957.

Taşkın, E. O. (2007). Stigmatization and discrimination in mental disorders. Taşkın, E.O. (Ed.), in Stigma attitudes towards mental illness and stigma (pp.31-40). İzmir: Meta Basım Matbaacilık.

Timurturkan, M., Demez, G., Kart, E., Ertan, C., Cankurtaran, S., \& Aktin, S. (2019). "Hükümlü" olmanın sosyal tezahürleri: sosyal dişlanma, damga ve suç [Social appearences of being an offender: Social exclusion, stigma and crime]. Mehmet Akif Ersoy University Journal of Social Sciences Institute, 9(20), 138157.

Thornberg, R. (2015). School bullying as a collective action: Stigma processes and identity struggling. Children E Society, 29(4), 310-320.

Tofur, S. (2018). Sinematografik anlatıda hersey-blanchard durumsal liderlik modelinin eğitimde kullanılabilirliği: Koro filmi [Hersey-Blanchard situational leadership model in cinematographic narration: Les choristes movie]. Journal of Theoretical Educational Science, 11(4), 822-837.

Vauth, R., Kleim, B., Wirtz, B., \& Corrigan, P. W. (2007). Self-efficacy and empowerment as outcomes of selfstigmatizing and coping in schizophrenia. Psychiatry Research, 150, 71-80.

Werner P., Aviv A., \& Barak Y. (2007). Self-stigma, self esteem and age in persons with schzophrenia. Int Psychogeriatr, 20, 174-87.

Verhaeghe M, Bracke P., \& Bruynooghe, K. (2008). Stigmatization and self-esteem of persons in recovery from mental illness: the role of peer support. Int J Soc Psychiatry, 54, 206-18.

Yang, H. S., Kleinman, A., Link, B. G., Phelan, J. C., Lee, S., \& Good, B. (2007). Culture and stigma: Adding moral experience to stigma theory. Social Science \& Medicine, 64, 1524-1535.

Yıldırım A., \& Şimşek H. (2013). Qualitative research methods in social sciences. (9nd Ed.). Ankara: Seçkin yayıncilik.

Yurdigül, A. (2014). Eğitim olgusunun sinematografik anlatıdaki yeri üzerine bir yaklaşım denemesi ("Bal” filmi örneği) [The testing of an approach to the place of education phenomena in cinematographic narration (The case of "Bal" movie)]. Ekev Academy Journal, 60(60), 487-502. 